\title{
Short Communication: \\ Diversity of plant species growing during fallow period of shifting cultivation and potential of its biomass for sustainable energy production in Mahakam Ulu, East Kalimantan, Indonesia
}

\author{
YULIANSYAH $^{1,2}$, MUHAMMAD TAUFIQ HAQIQI ${ }^{1}$, ELIS SEPTIA ${ }^{1}$, DEWI MUJIASIH ${ }^{1}$, \\ HELMI ALFATH SEPTIANA ${ }^{1}$, KRISNA ADIB SETIAWAN ${ }^{1}$, BUDHI SETIYONO $^{1}$, EDDY MANGOPO ANGI ${ }^{3}$, \\ SAPARWADI ${ }^{3}$, NUR MAULIDA SARI ${ }^{1}$, IRAWAN WIJAYA KUSUMA ${ }^{1,2}$, RUJEHAN $^{1,2}$, \\ WIWIN SUWINARTI ${ }^{1,2}$, RUDIANTO AMIRTA ${ }^{1,2 v}$ \\ ${ }^{1}$ Faculty of Forestry, Universitas Mulawarman. J1. Penajam, Gunung Kelua, Samarinda 75123, East Kalimantan, Indonesia. Tel./fax.: +62-541-748683. \\ vemail: ramirta@fahutan.unmul.ac.id \\ ${ }^{2}$ Graduate School of Forestry, Universitas Mulawarman. Jl. Penajam, Gunung Kelua, Samarinda 75123, East Kalimantan, Indonesia \\ ${ }^{3}$ Bioma Foundation. J1. AW. Syahrani, Perumahan Ratindo F7-8, Samarinda 75124, East Kalimantan, Indonesia
}

Manuscript received: 19 June 2019. Revision accepted: 21 July 2019

\begin{abstract}
Yuliansyah, Haqiqi MT, Septia E, Mujiasih D, Septiana HA, Setiawan KA, Setiyono B, Angi EM, Saparwadi, Sari NM, Kusuma IW, Rujehan, Suwinarti W, Amirta R. 2019. Short Communication: Diversity of plant species growing during fallow period of shifting cultivation and potential of its biomass for sustainable energy production in Mahakam Ulu, East Kalimantan, Indonesia. Biodiversitas 20: 2236-2242. Fallow period is a time gap, as long as 15 years, for improving natural soil fertility of land used for traditional shifting cultivation, in the tropical areas commonly used by Dayak People in Borneo Island. During this period, many biomass plant species naturally grow and develop a new forest vegetation community with shrub and medium trees, dominated by fastgrowing pioneer species. In this study, we investigated the plant diversity in fallowed shifting cultivation area in Batu Majang Village, Mahakam Ulu District, East Kalimantan Province, followed by analysis of the suitability of wood characteristics for energy production. We classified the study area according to the age of fallow period as: 1-3 years, 4-6 years, 7-9 years and 10-15 years. We found 29 species among which 13 were identified as the top species according to the highest value for important value index. Potential wood biomass production increased from $3.01 \mathrm{~m}^{3} \mathrm{ha}^{-1}$ to $399.62 \mathrm{~m}^{3} \mathrm{ha}^{-1}$. V. pinnata and M. pearsonii showed the highest dominance which is present in almost all area based on age classification groups. Wood from $V$. pinnata achieved the highest calorific valueof $18.00 \mathrm{MJ} \mathrm{kg}^{-1}$ whereas $N$. cadamba and M. sericea were in the second and third places with the value of $17.30 \mathrm{MJ} \mathrm{kg}^{-1} \mathrm{and}_{17.28} \mathrm{MJ} \mathrm{kg}^{-1}$, respectively. Therefore, $V$. pinnata was an important species among all other species observed because of high adaptability and high energy content. In addition, possible energy production at the end of the fallow period of 15 years was $2.92 \mathrm{GJ} \mathrm{ha}^{-1}$.
\end{abstract}

Keywords: Biomass, diversity, energy, fallow period, shifting cultivation

\section{INTRODUCTION}

As one of the tropical countries which have abundant plant biomass diversity and richness, and predicted future energy crisis, Indonesia has decided to start production of green energy and fuels from renewable sources (Amirta et al. 2016). Biomass is known as a renewable energy source which is considered as almost carbon neutral (Bilandzija et al. 2018). By using biomass combustion, it is possible to achieve reduction of net $\mathrm{CO}_{2}$ emission per unit of heating value, when compared to coal and natural gas (Eldabbagh et al. 2005). Agricultural crops, plant residues, forest resources and special energy plants are common biomass sources to produce energy (Avcioglu et al. 2019). The shrub species are also reported as good potential feedstock to provide sustainable energy (Dillen et al. 2013; Ghaley and Porter 2014; Hauk et al. 2014; Haverkamp and Musshoff 2014; Pérez et al. 2014; Krzyzaniak et al. 2015; Niemczyk et al. 2018; Gonzalez-Gonzalez et al. 2017; Amirta et al. 2016a; 2019; Martinez et al. 2019). On the other hand, investigation about unutilized biomass sources such as agricultural waste shows great promise as an alternative to cheap raw material. Agricultural waste was also reported as potential sustainable biomass for energyelectricity generation in some countries in the world (Arranz-pierra et al. 2018; Algieri et al. 2019; Bentsen et al. 2019; Huang et al. 2019; Morato et al. 2019).

Shifting cultivation is a traditional agricultural system in tropical regions, commonly used by local communities, including Dayak People of Borneo Island. To implement this farming system, farmers move to a new area to continue planting activity, leaving the old area after harvesting process, This creates a fallow period, as long as 15 years, to improve natural soil fertility. During this period, many biomass plant species grow in the fallow land and develop a new vegetation community with shrub and medium tree dominated by fast-growing pioneer species. The aim of this study is to investigate the plant diversity that grows during fallow period of shifting cultivation and their wood characteristics as feedstock for energy production. 


\section{MATERIALS AND METHODS}

\section{Study area}

This study was conducted in the post shifting cultivation area of Batu Majang Village, District of Mahakam Ulu, East Kalimantan Province, Indonesia $\left(115^{\circ} 12^{\prime} 17.550^{\prime \prime} \mathrm{E}, 0^{\circ} 33^{\prime} 3.039^{\prime \prime} \mathrm{N}\right)$. This village has an area of about 29.377 ha and annual temperature of 22 $34^{\circ} \mathrm{C}$, while the daily temperatures fluctuate between 3 $4^{\circ} \mathrm{C}$. The mean annual precipitation was $3,417 \mathrm{~mm}$, whereas the highest monthly rainfall was obtained in April and the lowest occurs in August amounted to $242 \mathrm{~mm}$, respectively. This area has also relatively high air humidity ranging between $81.42-87.07 \%$.

\section{Diversity of plant species}

Plant diversity found at the post shifting cultivation area of Batu Majang Village was studied by making 12 plots with a size of $20 \mathrm{~m} \times 20 \mathrm{~m}$. The diameter and height of the plant species were also measured. The herbarium specimens of all species were collected and deposited at
Laboratory of Dendrology and Forest Ecology, Faculty of Forestry, Mulawarman University, Samarinda, Indonesia for scientific identification of the species. In addition, the importance value index of each plant species found in the research area was calculated using the equation of MuellerDombois and Ellenberg as described and reported by Wiryono et al. (2016). The wood samples from species with highest important value index were collected and processed with debarking, chipping, powdering and airdrying process for further analysis.

\section{Measurement of wood physicochemical properties}

The physicochemical properties, such as moisture content, ash, volatile matter and fixed carbon of wood biomass collected from the plant species were determined according to the method of American Standart for Testing and Material (ASTM) D 7582-12: To determine the elemental composition (carbon-C, hydrogen- $\mathrm{H}$, and oxygen-O) and the wood calorific value, method proposed by Parikh et al. $(2005 ; 2007)$ was used.

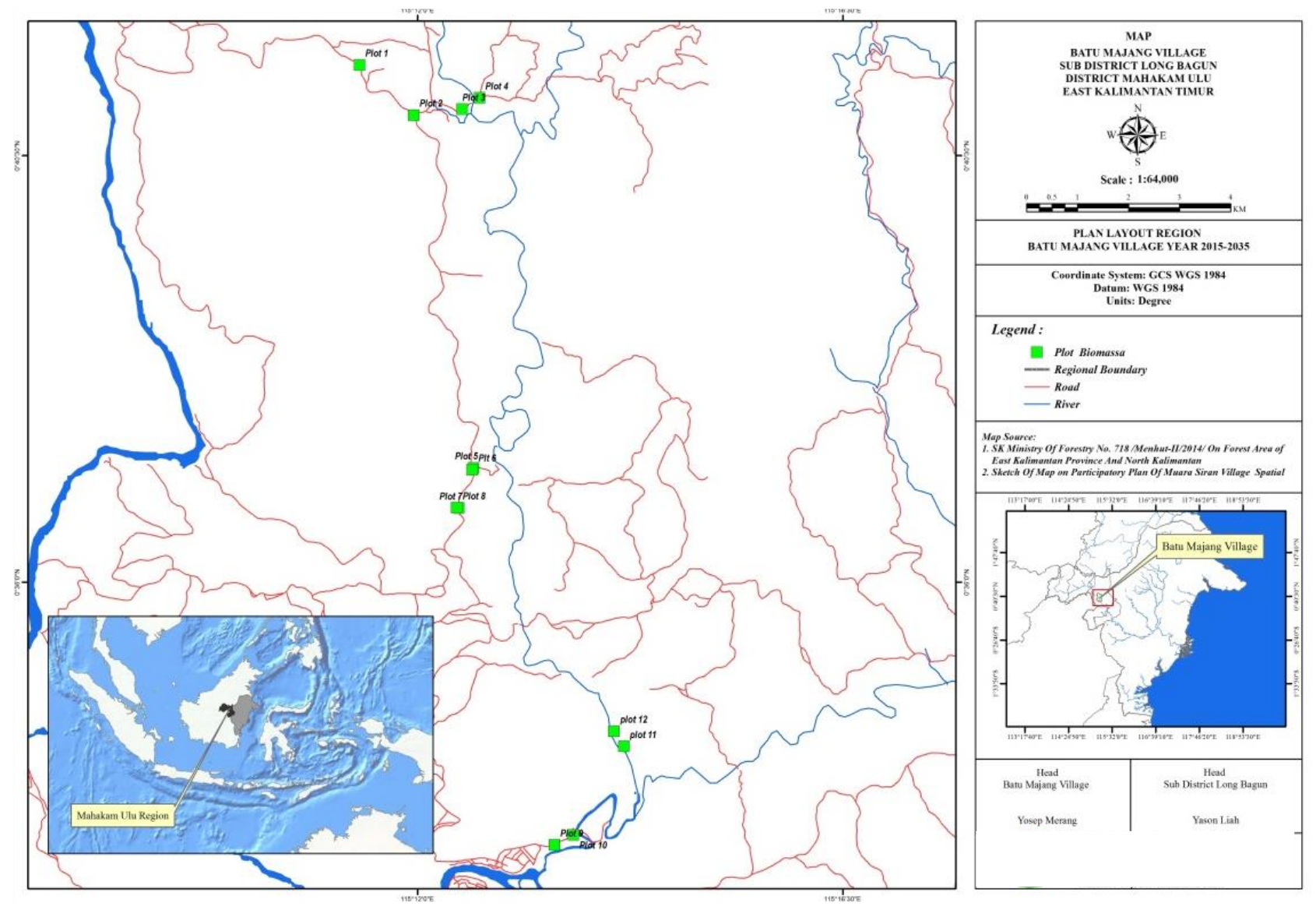

Figure 1. Research locations at Batu Majang Village, Mahakam Ulu, East Kalimantan, Indonesia 


\section{RESULTS AND DISCUSSION}

\section{Diversity of plant species}

Identification of biomass plant species collected from the research plots resulted in 29 species found growing in the community forests during fallow period of shifting cultivation. area. Those plant species were identified as Antidesma coriaceum Tul., Artocarpus elasticus Reinw. ex Blume, Bridelia glauca Blume, Bridelia tomentosa Blume, Callicarpa longifolia Lam., Cratoxylum sumatranum (Jack) Blume, Croton argyratus Blume, Cyathocalyx carinatus (Ridl.) J.Sinclair, Dyera costulata (Miq.) Hook.f., Ficus aurata (Miq.) Miq., Ficus uncinata (King) Becc., Glochidion obscurum (Roxb. ex Willd.) Blume, Hevea brasiliensis (Willd. ex A.Juss.) Müll.Arg., Leucaena leucocephala (Lam.) de Wit, Lithocarpus gracilis (Korth.) Soepadmo, Macaranga gigantea (Rchb.f. \& Zoll.) Müll.Arg., Macaranga hypoleuca (Rchb.f. \& Zoll.) Müll.Arg., Macaranga pearsonii Merr., Macaranga triloba (Thunb.) Müll.Arg., Madhuca sericea (Miq.) H.J.Lam, Melicope hookeri T.G.Hartley, Neolamarckia cadamba (Roxb.) Bosser, Neonauclea gigantea (Valeton) Merr., Piper aduncum L., Pterospermum javanicum Jungh., Shorea laevis Ridl., Syzygium polyanthum (Wight) Walp., Trema orientalis (L.) Blume, and Vitex pinnata L (Table 1).
Euphorbiaceae was the dominant family according to the highest importance value index measurements at all levels of age classification in shifting cultivation areas of Batu Majang Village, Mahakam Ulu District. Macaranga pearsonii was found with high dominance and was one among the top five species based on IVI, in in age categories of 1-3 years, 4-6 years and 7-9 years. Euphorbiaceae was reported as a pioneer family and its members such as $M$. gigantea, $M$. hypoleuca, $M$. pearsonii and $M$. triloba frequently occupied man places such as rocky outcrops, ruderal environments, disturbed areas, forest and road edges (Crepaldi et al. 2016). Kenzo et al. (2010) reported that Macaranga, Artocarpus, and Ficus are common plant species observed in regenerated secondary forest area after abandonment. Macaranga was also reported as the pioneer plant species that usually grow sporadically on the gap of forest canopy, and disturbed areas after forest fire or opening area for the shifting cultivation (Slik et al. 2003; Crepaldi et al. 2016). Moreover, shrub and tree species such as Melastoma and Macaranga were also traditionally used by Dayak people and local farmers in East Kalimantan as the natural key plant species indicator to determine the end of the recovery period of forest land after ground fire or shifting cultivation activities (Amirta et al. 2016b; Susanto et al. 2016; Imang et al. 2008).

Table 1. Plant species collected from the sampling plots located at fallow period of shifting cultivation area in Batu Majang Village

\begin{tabular}{|c|c|c|c|c|c|}
\hline Plant species & Family & Local name & Category & Utilization & Regeneration \\
\hline Antidesma coriaceum Tul. & Phyllanthaceae & Kayu Abu & Tree & Firewood & Natural \\
\hline Artocarpus elasticus Reinw. ex Blume & Moraceae & Talun/Taap & Tree & Food, Rope, Firewood & Artificial \\
\hline Bridelia glauca Blume & Phyllanthaceae & - & Tree & Firewood & Natural \\
\hline Bridelia tomentosa Blume & Phyllanthaceae & Serapak Lungun & Shrub & Furniture, Firewood & Natural \\
\hline Callicarpa longifolia Lam. & Lamiaceae & Belebu & Tree & Firewood & Natural \\
\hline Cratoxylum sumatranum (Jack) Blume & Hypericaceae & Duling & Tree & Construction, Firewood & Natural \\
\hline Croton argyratus Blume & Euphorbiaceae & - & Tree & Firewood & Natural \\
\hline Cyathocalyx carinatus (Ridl.) J.Sinclair & Annonaceae & Pudu & Tree & Food & Natural \\
\hline Dyera costulata (Miq.) Hook.f. & Apocynaceae & Jelutung & Tree & Furniture, Firewood & Artificial \\
\hline Ficus aurata (Miq.) Miq. & Moraceae & Abong & Tree & Firewood, Industrial & Natural \\
\hline Ficus uncinata (King) Becc. & Moraceae & Abong & Tree & Firewood, Food, Industrial & Natural \\
\hline $\begin{array}{l}\text { Glochidion obscurum (Roxb. ex Willd.) } \\
\text { Blume }\end{array}$ & Phyllanthaceae & Lengidan & Tree & Firewood, Construction & Natural \\
\hline $\begin{array}{l}\text { Hevea brasiliensis (Willd. ex A.Juss.) } \\
\text { Müll.Arg. }\end{array}$ & Euphorbiaceae & Karet & Tree & Industrial, Firewood & Artificial \\
\hline Leucaena leucocephala (Lam) de Wit & Fabaceae & Enep & Tree & Firewood, Food & Artificial \\
\hline Lithocarpus gracilis (Korth.) Soepadmo & Fagaceae & Palan & Tree & Firewood & Natural \\
\hline $\begin{array}{l}\text { Macaranga gigantea (Rchb.f. \& Zoll.) } \\
\text { Müll.Arg. }\end{array}$ & Euphorbiaceae & Jelak Bumbung & Tree & Firewood, Food, Medicine & Natural \\
\hline $\begin{array}{l}\text { Macaranga hypoleuca (Rchb.f. \& Zoll.) } \\
\text { Müll.Arg. }\end{array}$ & Euphorbiaceae & Benuaq Putih & Tree & Firewood & Natural \\
\hline Macaranga pearsonii Merr. & Euphorbiaceae & Ben & Tree & Fire & Natural \\
\hline Macaranga triloba (Thunb.) Müll.Arg. & Euphorbiaceae & Benuaq Putih & Tree & Firewood & Natural \\
\hline Madhuca sericea (Miq.) H.J.Lam & Sapotaceae & Sep & Tree & Construction, Food & Natural \\
\hline Melicope hookeri T.G.Hartley & Rutaceae & Besaii & Tree & Firewood & Natural \\
\hline Neolamarckia cadamba (Roxb.) Bosser & Rubiaceae & Kayu Tuak & Tree & Construction, Firewood & Natural \\
\hline Neonauclea gigantea (Valeton) Merr. & Rubiaceae & Tembalut & Tree & Firewood, Food & Natural \\
\hline Piper aduncum L. & Piperaceae & Kayu Uwa & Shrub & Firewood & Natural \\
\hline Pterospermum javanicum Jungh. & Malvaceae & Kidau & Tree & Construction, Firewood & Artificial \\
\hline Shorea laevis Ridl. & Dipterocarpaceae & Abanyit/Awang & Tree & Construction & Natural \\
\hline Syzygium polyanthum (Wight) Walp & Myrtaceae & Kayu Uba & Tree & Firewood, Medicine & Natural \\
\hline Trema orientalis $(\mathrm{L}$.$) Blume$ & Cannabaceae & Karun & Shrub & Firewood & Natural \\
\hline Vitex pinnata $\mathrm{L}$. & Lamiaceae & Temaa & Shrub & Firewood & Natural \\
\hline
\end{tabular}


Similarly, $V$. pinnata was also found as a dominant species. Both $M$. pearsonii and $V$. pinnata had high adaptability, especially in the beginning stages of succession to develop new vegetation after harvesting of crop plants. $V$. pinnata was commonly found in the secondary forests of Borneo Island and it is traditionally used by local people as a medicinal plant, especially for treating skin diseases (Kiyono and Hastaniah 2005; Arung et al. 2017; Goh et al. 2017).
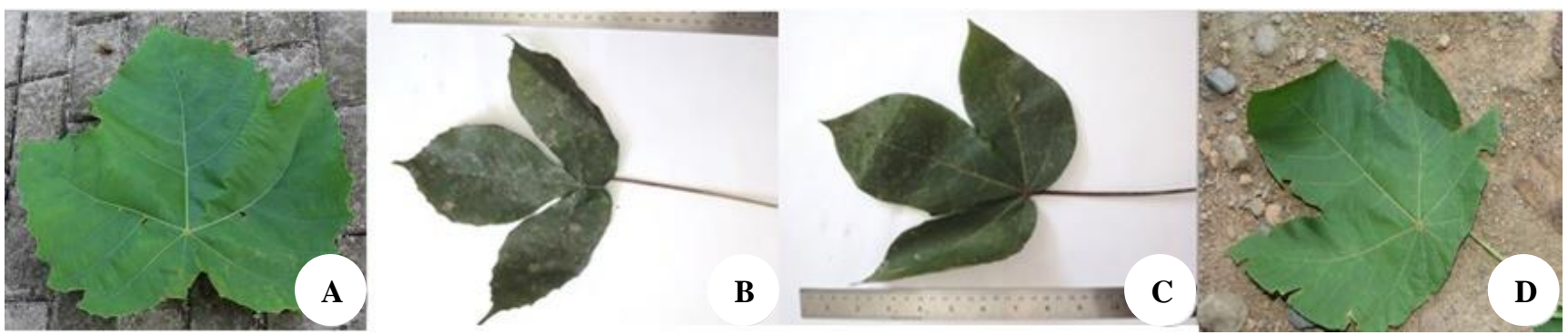

Figure 2. Leave shape of A. M. gigantea, B. M. hypoleuca, C. M. Pearsonii, D. M. Triloba

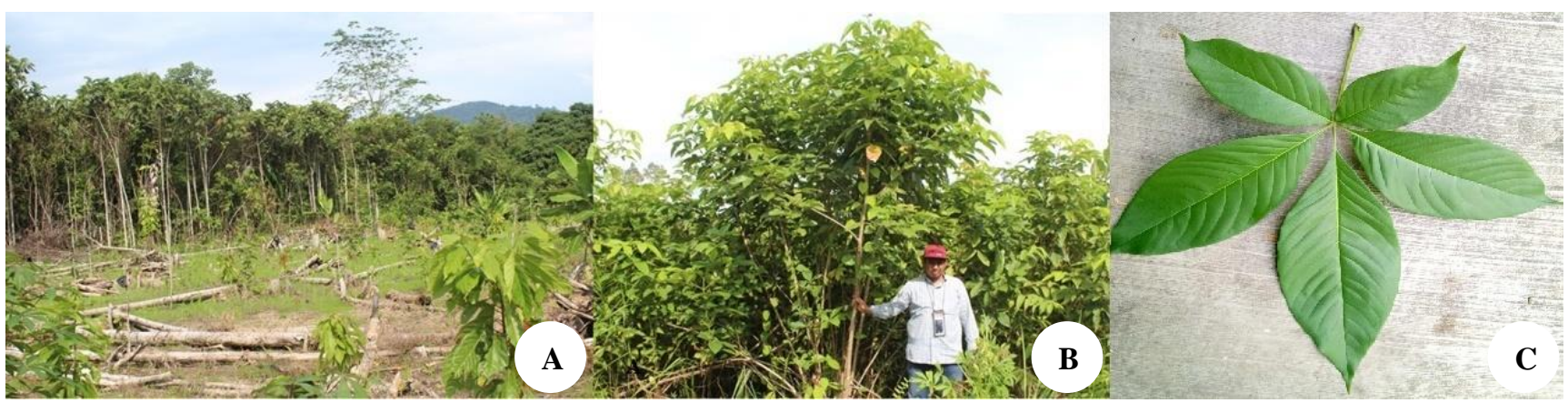

Figure 3. A. Shifting cultivation area, B. V. pinnata tree, C. Leaf of V. pinnata

Table 2. Top five species having the highest importance value index in different age classification

\begin{tabular}{|c|c|c|c|c|c|c|c|}
\hline Age classification & Species & Family & Local name & RDo & $\mathbf{R F}$ & RDe & IVI \\
\hline \multirow[t]{5}{*}{$1-3$ years } & $V \cdot$ pinnata & Lamiaceae & Temaa & 12.53 & 11.11 & 58.33 & 81.97 \\
\hline & L. gracilis & Fagaceae & Palan & 28.47 & 11.11 & 5.00 & 44.58 \\
\hline & M. pearsonii & Euphorbiaceae & Benuaq & 22.44 & 11.11 & 10.00 & 43.55 \\
\hline & F. uncinata & Moraceae & Abong & 3.62 & 11.11 & 11.67 & 26.40 \\
\hline & M. hypoleuca & Euphorbiaceae & Benuaq putih & 11.38 & 11.11 & 1.67 & 24.16 \\
\hline \multirow[t]{5}{*}{ 4-6 years } & N. gigantea & Rubiaceae & Tembalut & 36.85 & 10.00 & 33.33 & 80.18 \\
\hline & F. uncinata & Moraceae & Abong & 10.77 & 20.00 & 20.00 & 50.77 \\
\hline & $V$. pinnata & Lamiaceae & Temaa & 19.48 & 10.00 & 16.67 & 46.14 \\
\hline & M. gigantea & Euphorbiaceae & Jelak Bumbung & 13.04 & 10.00 & 10.00 & 33.04 \\
\hline & M. pearsonii & Euphorbiaceae & Benuaq & 7.82 & 10.00 & 6.67 & 24.49 \\
\hline \multirow[t]{5}{*}{ 7-9 years } & $V$. pinnata & Lamiaceae & Temaa & 44.44 & 20.00 & 27.27 & 91.71 \\
\hline & B. tomantosa & Phyllanthaceae & Serapak Lungun & 16.54 & 6.67 & 27.27 & 50.48 \\
\hline & M. gigantea & Euphorbiaceae & Jelak Bumbung & 10.78 & 6.67 & 9.09 & 26.54 \\
\hline & M. pearsonii & Euphorbiaceae & Benuaq & 4.81 & 6.67 & 9.09 & 20.57 \\
\hline & M. sericea & Sapotaceae & Sep & 8.27 & 6.67 & 3.03 & 17.96 \\
\hline \multirow[t]{5}{*}{$10-15$ years } & M. triloba & Euphorbiaceae & Benuaq Putih & 24.48 & 16.67 & 24.00 & 65.15 \\
\hline & M. hypoleuca & Euphorbiaceae & Benuaq Putih & 20.27 & 16.67 & 20.00 & 56.93 \\
\hline & H. brasiliensis & Euphorbiaceae & Karet & 13.66 & 8.33 & 20.00 & 39.60 \\
\hline & N. cadamba & Rubiaceae & Kayu Tuak & 11.27 & 8.33 & 8.00 & 30.00 \\
\hline & S. laevis & Dipterocarpaceae & Abanyit & 9.35 & 8.33 & 4.00 & 21.68 \\
\hline
\end{tabular}


Table 2. Diameter, height and available wood biomass in different age classification

\begin{tabular}{lccc}
\hline Age classification & $\begin{array}{c}\text { Diameter } \\
(\mathbf{c m})\end{array}$ & $\begin{array}{c}\text { Height } \\
(\mathbf{m})\end{array}$ & $\begin{array}{c}\text { Wood biomass } \\
\left(\mathbf{m}^{\mathbf{3}} \mathbf{h a} \mathbf{- 1}\right)\end{array}$ \\
\hline 1-3 years & 5.37 & 6.04 & 3.01 \\
4-6 years & 9.76 & 10.23 & 28.97 \\
7-9 years & 14.49 & 10.90 & 58.30 \\
10-15 years & 27.16 & 22.57 & 399.62 \\
\hline
\end{tabular}

\section{Wood characteristics of plant species}

The results from laboratory analysis showed that physicochemical properties of wood biomass of the species having highest important value index classified by age of the fallow period. Conversion into wood chip successfully reduced the amount of water in wood samples than those of greenwood condition, as shown in table 3. Low moisture content is important for wood to be suitable for solid fuel, for thermochemical conversion into energy (McKendry, 2002). In the present study, M. pearsonii, M. hypoleuca and
M. triloba were classified as species with low wood density $\left(<0.4 \mathrm{~g} / \mathrm{cm}^{3}\right)$. The lower wood density is related to fastgrowing ability of plant biomass species, thus affecting the cost of transport, storage and drying process (De Oleivera et al. 2013; Amirta et al. 2016a, 2016b, 2019).

Wood biomass from $V$. pinnata showed the highest calorific value (18.00 MJ kg-1). N. cadamba and $M$. sericea were in the second and third place with the calorific values of $17.30 \mathrm{MJ} \mathrm{kg}$ and $17.28 \mathrm{MJ} \mathrm{kg}$, respectively. Proximate analysis indicated that the average value of volatile matter was $70.29 \%$, fixed carbon was $17.20 \%$ and ash content was $1.42 \%$, whereas according to ultimate analysis, the average value of carbon was $44.32 \%$, hydrogen was $5.60 \%$ and oxygen was $46.77 \%$. Low ash proportion $(<5 \%)$ is indicative that the wood biomass is suitable to be used as a feedstock for gasifier reactors (Reed and Das, 1998). Composition of volatile matter and fixed carbon also affects high heating value causing flame stability during combustion (Virmond et al. 2012).

Table 3. Physical properties and calorific value of wood biomass species having the highest importance value index

\begin{tabular}{lcccc}
\hline \multicolumn{1}{c}{ Species } & $\begin{array}{c}\text { Moisture content } \\
\text { (greenwood) } \mathbf{( \% )}\end{array}$ & $\begin{array}{c}\text { Moisture content } \\
\text { (wood chip) } \mathbf{( \% )}\end{array}$ & $\begin{array}{c}\text { Wood density } \\
\left(\mathbf{g ~ c m}^{-3}\right)\end{array}$ & $\begin{array}{c}\text { Calorific value } \\
\left(\mathbf{M J} \mathbf{~ k g}^{-\mathbf{1}}\right)\end{array}$ \\
\hline V. pinnata & 21.43 & 8.57 & 0.55 & 18.00 \\
L. gracilis & 21.74 & 11.14 & 0.68 & 16.93 \\
M. pearsonii & 33.94 & 11.72 & 0.26 & 16.58 \\
F. uncinata & 60.27 & 9.40 & 0.56 & 15.44 \\
M. hypoleuca & 44.73 & 10.39 & 0.27 & 16.14 \\
B. tomantosa & 35.64 & 11.96 & 0.44 & 17.06 \\
M. gigantea & 41.99 & 10.46 & 0.51 & 16.84 \\
M. sericea & 46.22 & 9.46 & 0.61 & 17.28 \\
N. gigantea & 69.62 & 15.14 & 0.48 & 17.90 \\
M. triloba & 33.85 & 10.33 & 0.36 & 11 \\
H. brasiliensis & 39.80 & 9.16 & 0.61 & 17.93 \\
N. cadamba & 58.54 & 10.60 & 0.40 & 17.23 \\
S. laevis & 41.13 & 10.77 & 0.48 & 16.90 \\
Average & 42.22 & 10.70 & 0.48 & \\
\hline
\end{tabular}

Table 4. Proximate and ultimate analysis of wood biomass species with the highest importance value index

\begin{tabular}{|c|c|c|c|c|c|c|}
\hline \multirow{2}{*}{ Species } & \multicolumn{3}{|c|}{ Proximate $(\%)$} & \multicolumn{3}{|c|}{ Ultimate (\%) } \\
\hline & Volatile matter & Fixed carbon & Ash content & Carbon & Hydrogen & Oxygen \\
\hline$V$. pinnata & 71.67 & 19.32 & 1.04 & 43.29 & 5.86 & 50.73 \\
\hline L. gracilis & 70.48 & 16.82 & 1.21 & 44.32 & 5.98 & 49.62 \\
\hline M. pearsonii & 69.49 & 16.30 & 2.60 & 43.88 & 5.69 & 50.41 \\
\hline F. uncinata & 68.65 & 19.42 & 3.13 & 43.56 & 5.60 & 50.71 \\
\hline M. hypoleuca & 65.15 & 16.96 & 2.35 & 42.71 & 4.83 & 52.44 \\
\hline B. tomantosa & 69.50 & 17.62 & 1.18 & 44.30 & 5.74 & 49.86 \\
\hline M. gigantea & 68.60 & 19.40 & 1.54 & 43.60 & 5.44 & 38.55 \\
\hline M. sericea & 72.87 & 16.69 & 1.00 & 47.55 & 5.01 & 37.80 \\
\hline N. gigantea & 69.59 & 14.49 & 0.79 & 45.34 & 5.19 & 37.53 \\
\hline M. triloba & 71.07 & 17.08 & 1.14 & 44.85 & 5.87 & 49.22 \\
\hline H. brasiliensis & 73.77 & 15.36 & 0.88 & 42.12 & 6.10 & 51.50 \\
\hline N. cadamba & 72.01 & 16.63 & 0.77 & 47.37 & 5.30 & 39.33 \\
\hline S. laevis & 70.87 & 17.49 & 0.87 & 43.26 & 6.25 & 50.30 \\
\hline Average & 70.29 & 17.20 & 1.42 & 44.32 & 5.60 & 46.77 \\
\hline
\end{tabular}


Biomass productivity from the last cycle of fallow period (10-15 years old) reached an average of $399.62 \mathrm{~m}^{3}$ $\mathrm{ha}^{-1}$ (Table 2). After this period, the vegetation will be cleared and the farmers start new planting activity. The important step in shifting cultivation is burning of some wood biomass residue after fallow period to enhance soil fertility so more nutrition is available for crop plants (Thaler and Anandi 2017). In line with this finding, Fujiki et al. (2017) reported that biomass burning caused flushing of minerals originating from the burnt plant materials. On the other hand, farmers also leave behind some wood biomass at the planting areas which contributes to litter formation and organic matters, to prevent soil from undergoing erosion. In this case, we calculated the average available wood biomass returned for this purpose which was $61.31 \mathrm{~m}^{3} \mathrm{ha}^{-1}$. Our analysis showed that those wood biomasses contained energy of $2.92 \mathrm{GJ} \mathrm{ha}^{-1}$. Considering this high potency, we also analyzed benefits from the utilization of energy feedstock. First, it can be a new alternative for sustainable heat and electricity for development of remote areas in East Kalimantan province. Second, the waste from energy biomass such as ash can be an alternative to provide mineral nutrients for next agricultural plant on shifting cultivation. We believe that it can be a suitable application towards development of green energy production combined, along with green agricultural system to maintain the green environment.

\section{ACKNOWLEDGEMENTS}

This work was financially supported by the grant of the Ministry of Research, Technology and Higher Education of Indonesia, Ristekdikti (Grant No. 135/UN17.41/KL/ 2018 for RA). Special thanks also addressed to BAPPEDA of Mahakam Ulu District. We are grateful to Akhmad Wijaya of Bioma Foundation, Samarinda for valuable discussions on the local basic policy of wood biomass utilization for energy and electricity in East Kalimantan Province, Indonesia.

\section{REFERENCES}

Algieri A, Andiloro S, Tamburino V, Zema DA. 2019. The potential of agricultural residues for energy production in Calabria (Southern Italy). Renew Sust Energ Rev 104: 1-14.

Amirta R, Yuliansyah, Angi EM, Ananto BR, Setiyono B, Haqiqi MT, Septianan HA, Londong M, Oktavianto RN. 2016a. Plant diversity and energy potency of community forest in East Kalimantan, Indonesia: Searching for fast growing wood species for energy production. Nusantara Biosci 8 (1): 22-31.

Amirta R, Nafitri SI, Wulandari R, Yuliansyah, Suwinarti W, Candra KP, Watanabe T. 2016b. Comparative characterization of Macaranga species collected from secondary forests in East Kalimantan for biorefinery of unutilized fast growing wood. Biodiversitas 17 (1): 116-123.

Amirta R, Haqiqi MT, Saparwadi, Septia E, Mujiasih D, Setiawan KA, Sekedang MA, Yuliansyah, Wijaya A, Setiyono B, Suwinarti W. 2019. Searching for potential wood biomass for green energy feedstock: A study in tropical swamp-peat forest of Kutai Kertanegara, Indonesia. Biodiversitas 20 (6): 1516-1523.
Arung ET, Pasedan WF, Kusuma IW, Hendra M, Supriadi MB. 2017. Short Communication: Selected medicinal plants in East and North Kalimantan (Indonesia) against Propionibacterium acnes. Biodiversitas 18 (1): 321-325.

Arranz-Piera P, Kemausuor F, Darkwah L, Edjekumhene I, Cortes J, Velo E. 2018. Mini-grid electricity service based on local agricultural residues: Feasibility study in rural Ghana. Energy 153: 443-454.

Avcioglu AO, Dayıglu MA, Türker U. 2019. Assessment of the energy potential of agricultural biomass residues in Turkey. Renew Energ 138: 610-619.

Bentsen NS, Jørgensen JR, Stupak I, Jørgensen I, Taghizadeh-Toosi A. 2019. Dynamic sustainability assessment of heat and electricity production based on agricultural crop residues in Denmark. J Cleaner Prod 213: 491-507.

Bilandzija N, Voca N, Jelcic B, Jurisic V, Matin A, Grubor M, Kricka T. 2018. Evaluation of Croatian agricultural solid biomass energy potential Renew Sust Energ Rev 93: 225-230.

Crepaldi CG, Campos JLA, Albuquerque UP, Sales MF. 2016. Richness and ethnobotany of the family Euphorbiaceae in a tropical semiarid landscape of Northeastern Brazil. S Afr J Bot 102: 157-165.

De Oliveira JL, da Silva JN, Pereira EG, Filho DO, Carvalho DR. 2013. Characterization and mapping of waste from coffee and eucalyptus production in Brazil for thermochemical conversion of energy via gasification. Renew Sust Energ Rev 21: 52-58.

Dillen SY, Djomo SN, Al Afas N, Vanbeveren S, Ceulemans R. 2013. Biomass yield and energy balance of a short-rotation poplar coppice with multiple clones on degraded land during 16 years. Biomass Bioenerg 56: 157-165.

Eldabbagh F, Ramesh A, Hawari J, Hutny W, Kozinski JA. 2005. Particlemetal interactions during combustion of pulp and paper biomass in a fluidized bed combustor. Combust Flame 142: 249-57.

Fujiki S, Nishio S, Okada K, Nais J, Kitayama K. 2017. Plant communities and ecosystem processes in a succession-altitude matrix after shifting cultivation in the tropical montane forest zone of northern Borneo. J Trop Ecol 33: 33-49.

Ghaley BB, Porter JR. 2014. Determination of biomass accumulation in mixed belts of Salix, Corylus and Alnus species in combined food and energy production system. Biomass Bioenerg 63: 86-91.

Goh MPY, Basri AM, Yasin H, Taha H, Ahmad N. 2017. Ethnobotanical review and pharmacological properties of selected medicinal plants in Brunei Darussalam: Litsea elliptica, Dillenia suffruticosa, Dillenia excelsa, Aidia racemosa, Vitex pinnata and Senna alata. Asian Pac J Trop Med 7 (2): 173-180.

Gonzalez-Gonzalez BD, Sixto H, Alberdi I, Esteban L, Guerrero S, Pasalodos M, Vazquez A, Canellas I. 2017. Estimation of shrub biomass availability along two geographical transects in the Iberian Peninsula for energy purposes. Biomass Bioenerg 105: 211-218.

Hauk S, Wittkopf S, Knoke T. 2014. Analysis of commercial short rotation coppices in Bavaria, southern Germany. Biomass Bioenerg 67: 401-412.

Haverkamp MW, Musshoff O. 2014. Are short rotation coppices an economically interesting form of land use? A real options analysis. Land Use Policy 38: 163-174.

Huang Y, Zhao Y, Hao Y, Wei G, Feng J, Li W, Yia Q, Mohamed U, Pourkashanian M, Nimmo W. 2019. A feasibility analysis of distributed power plants from agricultural residues resources gasification in rural China. Biomass Bioenerg 121: 1-12.

Imang N, Inoue M, Sardjono MA. 2008. Tradition and the influence of monitary economy in swidden agriculture among the Kenyah People of East Kalimantan, Indonesia. Int J Soc For 1 (1): 61-82.

Kenzo T, Ichie T, Hattori D, Kendawang JJ, Sakurai K, Ninomiya I. 2010. Changes in above-and belowground biomass in early successional tropical secondary forests after shifting cultivation in Sarawak, Malaysia. For Ecol Manag 260: 875-882.

Kiyono Y, Hastaniah. 2005. Patterns of slash-and-burn land use and their effects on forest succession: Swidden-land forests in Borneo. Bull For For Prod Res Inst 4 (4): 259-282.

Krzyzaniak M, Stolarski MJ, Szczukowski S, Tworkowski J, Bieniek A, Mleczek M. 2015. Willow biomass obtained from different soils as a feedstock for energy. Ind Crop Prod 75: 114-121.

Martinez CLM, Rocha EPA, Carneiro ACO, Gomes FJB, Batalha LAR, Vakkilainen E, Cardoso M. 2019. Characterization of residual biomasses from the coffee production chain and assessment the potential for energy purposes. Biomass Bioenerg 120: 68-76. 
McKendry P. 2002. Energy production from biomass (part 1): overview of biomass. Bioresource Technol 83: 37-46.

Morato T, Vaezi M, Kumar A. 2019. Assessment of energy production potential from agricultural residues in Bolivia. Renew Sust Energ Rev 102: 14-23.

Niemczyk M, Kaliszewski A, Jewiarz M, Wróbel M, Mudryk K. 2018. Productivity and biomass characteristics of selected poplar (Populus spp.) cultivars under the climatic conditions of northern Poland. Biomass Bioenerg 111: 46-51.

Parikh L, Channiwala SA, Ghosal GK. 2005. A correlation for calculating HHV from proximate analysis of solid fuels. Fuel, 84: 487-494.

Parikh L, Channiwala S.A, Ghosal G.K. 2007. A correlation for calculating elemental composition from proximate analysis of biomass materials. Fuel 86: 1710-1719.

Pérez S, Renedo CJ, Ortiz A, Delgado F, Fernández I. 2014. Energy potential of native shrub species in northern Spain. Renew Energ 62: 79-83.

Reed TB, Das A. 1988. Handbook of downdraft gasifier engine systems. Golden, Colo: Solar Technical Information Program, Solar Energy Research Institute, Golden, CO.
Susanto D, Ruhiyat D, Sutisna M, Amirta R. 2016. Soil and leaf nutrient status on growth of Macaranga gigantea in secondary forest after shifting cultivation in East Kalimantan, Indonesia. Biodiversitas 17 (2): 409-416

Slik, JWF, Keßler PJA, Welzen PCV. 2003. Macaranga and Mallotus species (Euphorbiaceae) as indicators for disturbance in the mixed lowland dipterocarp forest of East Kalimantan (Indonesia). Ecol Indic 2: 311-324.

Thaler GM, Anandi CAM. 2017. Shifting cultivation, contentious land change and forest governance: the politics of swidden in East Kalimantan. J Peasant Stud 44 (5): 1066-1087.

Virmond E, De Sena RF, Albrecht W, Althoff CA, Moreira RF, Jose HJ. 2012. Characterisation of agroindustrial solid residues as biofuels and potential application in thermochemical processes. Waste Manag 32 (10): 1952-1961.

Wiryono, Puteri VNU, Senoaji G. 2016. The diversity of plant species, the types of plant uses and the estimate of carbon stock in agroforestry system in Harapan Makmur Village, Bengkulu, Indonesia. Biodiversitas 17 (1): 249-255. 